\title{
Qualitative Characteristics of Varieties and Lines of Winter Triticale Representing Production and Breeding Interest
}

\author{
Aleksandr Subbotin*, Natalia Stepanova, and Irina Kanevskaya \\ Federal State-Owned Publicly-Funded Institution Of Higher Education Saratov SAU named after N.I. \\ Vavilov, 410012, 1 Teatralnaya Ploshchad Str., Saratov, Russia
}

\begin{abstract}
The article presents the results of evaluating varieties and lines of winter triticale for various indicators of grain quality, which are of great importance in production and breeding. On average, over the years of research, a higher protein content in grain was found in lines $32 / 4$ $(13.33 \%)$ and $29 / 1(13.23 \%)$. The studied varieties and lines had a high content of good quality gluten, varying from $24.1 \%$ (line $28 / 1$ ) to $35.3 \%$ (cultivar Bard). All varieties and lines of winter triticale, except for the Orlik variety, correspond to the first quality group.
\end{abstract}

\section{Introduction}

In accordance with modern technologies of adaptive crop production, cultigen varieties shall most fully and effectively use the natural components of agroecosystems; have resistance to abiotic and biotic environmental factors that negatively affect the volume and quality of the crop; ensure resource and energy efficiency, environmental plasticity, environmental protection and profitability of agricultural production. Creation of varieties that meet these requirements is considered a priority area of adaptive crop production in the Volga region, since microzones of agricultural production are characterized by low moisture availability and dramatically changing environmental conditions. It is the adaptive ability of the variety that contributes to the genotype in the process of ontogenesis to adapt to changing environmental conditions, determining its ability to form maximum productivity in unfavorable conditions, and to use them with the greatest efficiency in favorable conditions. The triticale culture fully meets the listed requirements, is considered highly adaptive and, due to the combination of valuable biological and economic traits and properties, is gaining increasing popularity among farmers $[2,10]$.

Triticale grain is used in feed, bakery, confectionery, alcohol industry, as well as in the production of beer and kvass. The studies carried out in recent years by scientists of our country on formation and assessment of the consumer properties of flour from triticale grain made it possible to develop requirements for the products produced. Considering the modern trends in flour production at enterprises, control methods, safety indicators, requirements for transportation and storage, which were the basis for developed standard

\footnotetext{
* Corresponding author: subbotinag2014@mail.ru
} 
GOST 34142-2017 "Triticale Flour. Specifications". The standard provides for division of triticale flour into five grades: T-60, T-70, T-80, T-120, T-220 [1,8,13].

Requirements for the quality of flour of each grade are justified by the results of research works, depending on the level of organoleptic indicators of the quality of flour taste, smell, color, as well as physical and chemical indicators, the most important of which are ash content, whiteness, quantity and quality of gluten, falling number and the grind size [3-7, 11-12].

The purpose of the study is to study varieties and lines of winter triticale according to important quality indicators with the aim of their further use in production and breeding process.

\section{Methods}

The study of the experimental material was carried out in field experiments in the period from 2017 to 2019 in the territory of the experimental field of Federal State-Owned Publicly-Funded Institution of Higher Education SSAU named after N.I. Vavilov. Triticale varieties entered in the State Register of Breeding Achievements, as well as lines created at the Department of Plant Growing, Breeding and Genetics of the Saratov State Agrarian University, were used as research material.

Eating of the selection seed material was carried out on black fallow in late August early September, depending on weather conditions. The seeding rate is 350 germinating seeds per $1 \mathrm{~m}^{2}$. Arrangement of field trials, phenological records, laboratory analyzes were carried out in accordance with the methodology of the state variety testing of agricultural crops [9]. The content of protein and gluten was determined using Inframatic-8100 device, the principle of which is based on measuring the intensities of optical radiation diffusely reflected from the test sample in the near infrared region of the spectrum; the quality of gluten - device IDK-3M; indicator SDS-sedimentation - according to the method of V.M. Bebyakin and M.V. Buntina (State Scientific Research Institute of Agriculture of the South-East).

\section{Results}

In the experiment, in lines and varieties of winter triticale, the protein content in grain varied within the range of 11.93 (Cornet) - $13.3 \%$ (line 32/4). In dry years, when moisture deficit was observed during the growing season at high temperatures, much more protein was formed in caryopsis (2017 and 2018) and less in relatively humid years (2019) (Table $1)$.

Table 1. Evaluation of varieties and lines of triticale by protein content in grain, \%.

\begin{tabular}{|c|l|c|c|c|c|}
\hline $\begin{array}{c}\text { Ser. } \\
\text { No. }\end{array}$ & Variety, line & $\mathbf{2 0 1 7}$ & $\mathbf{2 0 1 8}$ & $\mathbf{2 0 1 9}$ & Average \\
\hline 1 & Orlik & 13.8 & 13.5 & 9.4 & 12.23 \\
\hline 2 & Yubileynaya & 15.2 & 13.9 & 9.3 & 12.80 \\
\hline 3 & $\begin{array}{l}\text { Student } \\
\text { (standard) }\end{array}$ & 13.9 & 15.5 & 9.8 & 13.07 \\
\hline 4 & Sargau & 14.6 & 13.1 & 9.9 & 12.53 \\
\hline 5 & Yasha & 13.9 & 13.8 & 9.7 & 12.37 \\
\hline 6 & Bard & 14.6 & 13.5 & 10.0 & 12.70 \\
\hline 7 & Zhitnitsa & 13.1 & 14.0 & 9.6 & 12.23 \\
\hline 8 & Kornet & 12.5 & 14.0 & 9.3 & 11.93 \\
\hline 9 & Ti17 & 13.3 & 14.6 & 9.0 & 12.30 \\
\hline
\end{tabular}




\begin{tabular}{|c|l|c|c|c|c|}
\hline $\begin{array}{r}\text { Ser. } \\
\text { No. }\end{array}$ & Variety, line & $\mathbf{2 0 1 7}$ & $\mathbf{2 0 1 8}$ & $\mathbf{2 0 1 9}$ & Average \\
\hline 10 & Line 28/1 & 14.1 & 13.9 & 10.2 & 12.77 \\
\hline 11 & Line 29/1 & 14.1 & 15.6 & 10.1 & 13.23 \\
\hline 12 & Line 29/5 & 14.9 & 13.8 & 9.5 & 12.70 \\
\hline 13 & Line 32/4 & 14.4 & 14.5 & 11.1 & 13.33 \\
\hline 14 & Line 32/7 & 13.3 & 14.6 & 9.4 & 12.43 \\
\hline NSR 05 & 0.54 & 0.68 & 0.43 & 0.63 \\
\hline
\end{tabular}

On average, in the experiment, the varieties and lines of winter triticale showed a high content of gluten, which is of good quality, Table 2 .

Table 2. The quantity and quality of gluten in grain lines and varieties of winter triticale (average for 2017-2019).

\begin{tabular}{|c|c|c|c|c|}
\hline \multirow{2}{*}{$\begin{array}{l}\text { Ser. } \\
\text { No. }\end{array}$} & \multirow{2}{*}{ Variety, line } & \multirow{2}{*}{$\begin{array}{c}\text { Crude gluten } \\
\text { content, } \%\end{array}$} & \multicolumn{2}{|c|}{ Indicator } \\
\hline & & & $\begin{array}{c}\text { IDK-3M, seed } \\
\text { unit }\end{array}$ & sedimentation \\
\hline 1 & Orlik & 27.0 & 80.0 & 37 \\
\hline 2 & Yubileynaya & 28.3 & 78.0 & 37 \\
\hline 3 & $\begin{array}{l}\text { Student } \\
\text { (standard) }\end{array}$ & 32.5 & 81.0 & 30 \\
\hline 4 & Sargau & 31.5 & 72.3 & 41 \\
\hline 5 & Yasha & 32.8 & 79.0 & 34 \\
\hline 6 & Bard & 35.3 & 80.0 & 27 \\
\hline 7 & Zhitnitsa & 32.5 & 76.0 & 37 \\
\hline 8 & Kornet & 31.4 & 75.9 & 38 \\
\hline 9 & Ti 17 & 28.6 & 73.0 & 35 \\
\hline 10 & Line 28/1 & 24.0 & 75.0 & 34 \\
\hline 11 & Line $29 / 1$ & 31.5 & 78.0 & 33 \\
\hline 12 & Line $29 / 5$ & 26.3 & 70.0 & 34 \\
\hline 13 & Line $32 / 4$ & $28 / 3$ & 77.5 & 33 \\
\hline 14 & Line $32 / 7$ & 27.4 & 72.1 & 36 \\
\hline \multicolumn{2}{|c|}{$\mathrm{NSR}_{05}$} & 1.44 & 3.40 & 1.72 \\
\hline
\end{tabular}

Dependence of duration of baking bread on the temperature regime and the qualitative composition of gluten proteins is shown in Table. 3 .

Table 3. Assessment of lines and varieties of winter triticale in terms of reaction rates and falling number in the meal (average for 2017-2019, laboratory of grain biochemistry of Federal State Funded Research Institution Southeast Agricultural Research Institute).

\begin{tabular}{|c|l|c|c|c|c|}
\hline \multirow{2}{*}{$\begin{array}{c}\mathbf{N} \\
\mathbf{0}\end{array}$} & \multirow{2}{*}{ Variety, line } & \multicolumn{3}{|c|}{ Indicators of reaction rates } & \multirow{2}{*}{$\begin{array}{c}\text { Falling } \\
\text { number } \\
\text { (PN) }\end{array}$} \\
\cline { 3 - 5 } & & $\boldsymbol{\alpha}$ & $\boldsymbol{\beta}$ & $\boldsymbol{\gamma}$ & 161 \\
\hline 1 & Orlik & -0.028 & 0.524 & -0.078 & 257 \\
\hline 2 & Yubileynaya & -0.042 & 0.494 & -0.084 & 257 \\
\hline 3 & Student & -0.032 & 0.558 & -0.066 & 220 \\
\hline 4 & Sargau & -0.036 & 0.506 & -0.102 & 315 \\
\hline 5 & Yasha & -0.034 & 0.488 & -0.066 & 163 \\
\hline 6 & Bard & -0.042 & 0.362 & -0.106 & 262 \\
\hline 7 & Zhitnitsa & -0.043 & 0.482 & -0.083 & 330 \\
\hline 8 & Kornet & -0.042 & 0.660 & -0.080 & 227 \\
\hline 9 & Ti 17 & -0.044 & 0.680 & -0.074 & \\
\hline
\end{tabular}




\begin{tabular}{|c|c|c|c|c|c|}
\hline \multirow{2}{*}{$\begin{array}{c}\mathbf{N} \\
\mathbf{0}\end{array}$} & \multirow{2}{*}{ Variety, line } & \multicolumn{3}{|c|}{ Indicators of reaction rates } & Falling \\
\cline { 3 - 6 } & & $\boldsymbol{\alpha}$ & $\boldsymbol{\beta}$ & $\boldsymbol{\gamma}$ & $\begin{array}{c}\text { number } \\
\text { (PN) }\end{array}$ \\
\hline 10 & Line 28/1 & -0.048 & 0.468 & -0.068 & 253 \\
\hline 11 & Line 29/1 & -0.038 & 0.090 & 0.610 & 306 \\
\hline 12 & Line 29/5 & -0.050 & 0.412 & -0.068 & 234 \\
\hline 13 & Line 32/4 & -0.044 & 0.476 & -0.120 & 228 \\
\hline 14 & Line 32/7 & -0.040 & 0.690 & -0.080 & 278 \\
\hline \multicolumn{5}{|l|}{ NSR 05 } \\
\hline
\end{tabular}

\section{Discussion}

Research on selection and testing the triticale varieties with a high protein content in grain is associated with a number of difficulties, namely: high phenotypic variability of the trait, rare occurrence of recessive mutations, complicated expression of mutant genes, linked inheritance of genes that control protein, with negative traits, lack of morphological markers. Triticale grains are generally characterized by a high protein content and high quality. Genotypes with a significant protein content in grain relatively stably maintain its high level over the years, regardless of environmental conditions, which indicates the genetic predetermination of this indicator [10].

In 2017 , the protein in caryopses contained within $12.5 \%$ (Kornet variety) $-15.2 \%$ (Yubileinaya variety), in new lines 13.3 (line 32/7) - 14.9\% (line 29/5).

In 2018, the protein content varied within $13.1-15.6 \%$, in lines - 13.8 (line 29/5) $15.6 \%$ (line 29/1). In 2019, less than others, the protein content in grain was found in Ti 17 variety $-9.0 \%$, and more in the $32 / 4$ line $-11.1 \%$. In the lines, the protein content in the caryopses was within the range of 9.4 (line 32/7) - $11.1 \%$ (line 32/4).

In varieties intended for food use, along with protein and its balanced amino acid composition, the grain shall have good baking properties, depending on the quantity and quality of gluten. Gluten proteins are mainly represented by prolamins, and they are poor in lysine [7-8].

A balanced ratio of protein fractions of glutenins and gliadins is also of paramount importance in assessing the baking properties of triticale flour. When kneading the dough, these fractions form a sticky substance with water. In triticale flour, the content of glutenins and gliadins is lower than in wheat flour [1,7-8].

A big plus is the content of such a protein component as lysine in the gluten complex of triticale grain, which explains the high biological value of the triticale protein in comparison with other cereals.

In general, the studied varieties and lines of winter triticale contained a fairly large amount of gluten proteins in the grain - from $24.1 \%$ (line 28/1) to $35.3 \%$ (Bard variety). A high gluten content was found in the varieties Yasha (32.8 \%), Zhitnitsa (32.5\%), line 29/1 of hybrid origin (Kornet/Sargau) (31.5\%), Kornet (31.4\%), Sargau ( $31.5 \%)$. The coefficient of variation of the trait was within $14.5 \%$.

The deformation index on the IDK-1 device and the sedimentation index were determined from the gluten quality indicators, i.e. swelling of gluten proteins in weak solutions of acetic, lactic and other weak acids. Strong gluten swells well, holds firmly, weak gluten swells a little, and the solution becomes cloudy. The sedimentation index ranged from 10-80 $\mathrm{ml}$ and more. Indicators 60 and above are typical for varieties with strong gluten, $40-60 \mathrm{ml}$ - for varieties with good gluten quality and $20-40 \mathrm{ml}$ for varieties with a low protein content, or with defective gluten [4]. According to the results of the sedimentation index, only the Sargau variety went beyond 40 units, the rest had an assessment within 20-40 units of the device, which makes it possible to classify them as 
low-quality. It is impossible to obtain bread of satisfactory quality from flour with such a gluten quality; the variation in the characteristic is $4.22 \%$.

According to the IDC indicator, all varieties and lines isolated from hybrid populations were assigned to the group with high-quality strong gluten; the variation in the trait was $4.77 \%$.

It is known that rheological properties are a complex indicator that describes the state and behavior of the dough during mixing and throughout the entire technological process. Information about the dough's extensibility, its elasticity and water absorption capacity characterizes the quality of the finished product. In this regard, new unconventional indicators of the physical properties of the dough, assessed using the Mixolab device, are of great interest, which makes it possible to determine the interaction of all flour components in the process of kneading and forming the dough, the activity of enzymes, and even predict the resistance of bread baked from the test flour to staleness. In addition, this device allows to create new experimental protocols with both constant and changing values of temperature, time, ratio of components, etc. depending on the goals and objectives set for the experimenter [4-6,11-12].

The study of quality indicators was carried out in the mode of changing temperatures at a fixed deformation load in the protocols of the Mixolab device.

Indicator $\alpha$ characterizes the relationship between the state of the dough immediately after its formation, the duration of the process of weakening of proteins, i.e. thinning the dough. As the temperature rises, the viscosity of the dough decreases, the degree of which depends on the quality of the protein.

Section $\beta$ characterizes the process of starch gelatinization, depending on the temperature regime. The viscosity of the dough rises with temperature increase. The rate of this increase depends on the quality of the starch and sometimes the additives.

The $\gamma$ index characterizes the relationship of amylase activity. The stronger the drop in viscosity, the higher the amylase activity, which is associated with the rate of seed germination on the root [4].

Duration of individual moments when baking bread, from kneading the dough to obtaining the finished product, depends on the temperature regime and the qualitative composition of gluten proteins.

Falling number (FN) - the total time in seconds from the beginning of the formation of the dough until the complete gelatinization of the water-flour suspension. According to the FN and the viscosity of the water-flour suspension of whole milled grain according to the amylograph, four groups of grain quality are determined: 1) the FN is more than 200 seconds and the viscosity is over 600 units of the amylograph; 2) 140-200 and 350-600;3) $80-140$ and $150-350 ; 4)$ less than 80 seconds and less than 150 units of the amylograph [4$6]$.

Among the evaluated varieties and lines, only the Orlik variety can be attributed to the 2nd quality group, the rest correspond to the highest first quality group.

Therefore, it can be stated that the existing potential of varieties and lines isolated from hybrid populations is of certain interest in using it as a starting material when creating new varieties and hybrid populations for subsequent selections for grain quality.

\section{Conclusion}

The amount of protein in grain of different varieties and lines was within the range of 11.93 (Kornet) - 13.3 (line 32/4). In dry years, when during the growing season of plants there was a deficiency of soil and atmospheric moisture at high temperatures, much more protein was formed in caryopses. As a starting material for increasing protein in grain, the best lines are 32/4 (13.3\%) and 29/1 (13.2\%), as well as the Student variety (13.0\%). In terms 
of gluten content - Bard (35.3\%), Yasha (32.8\%), Student and Zhitnitsa (32.5\% each) varieties.

Varieties of Yasha (32.8\%), Zhitnitsa (32.5\%), line 29/1 of hybrid origin (Kornet/Sargau) (31.5\%), Kornet (31.4\%), Sargau (31.5\%) distinguished themselves in terms of the content of raw gluten in grain. In the rest of the varieties and lines, the value of this indicator was significantly lower compared to the standard average.

According to the results of measuring the gluten deformation index, all cultivars and lines isolated from hybrid populations were assigned to the group with high-quality strong gluten, the variation of the trait was within $4.77 \%$, and in terms of sedimentation, the Sargau cultivar turned out to be the best (41 seed units) with a coefficient of variation of the feature of $4.22 \%$.

Orientation according to the phases of the Mixolab rheological analysis allows to determine the typology of flour (low, medium, strong and very strong) and its purpose (puff pastry, crackers, noodles, tin bread, tortilla or as an improver for mixtures).

\section{References}

1. I.S. Vitol, T.P. Karpilenko, R.H. Kandrokov, A.A. Starichenkov, A.I. Koval', N.S. ZHil'cova, Hranenie i pererabotka sel'hozsyr'ya, 8 (2015)

2. A.I. Grabovec, A.V. Krahmal', Itogi i perspektivy selekcii ozimogo tritikale na Donu (Rostov na Donu, 2014)

3. N.M. Derkanosova, M.A. Kalina,Tovaroved prodovol'stvennyh tovarov, 6 (2010)

4. A. Dyuba, K.D. Rysev, Upravlenie reologicheskimi svojstvami pishchevyh produktov (Moskva, MGUPP, 2008)

5. O.E. Karchevskaya, Hlebopechenie Rossii, 3 (2011)

6. O.E. Karchevskaya, G.F. Dremucheva, A.A. Grabovec, V.YA. Kovtunenko, Pishchevaya industriya (2011)

7. E.P. Meleshkina, I.A. Pankrat'eva, O.V. Polituha, L.V. CHirkova, N.S. ZHil'cova, Hleboprodukty, 2 (2015)

8. E. P. Meleshkina, Hleboprodukty, 7 (2015)

9. Metodika gosudarstvennogo sortoispytaniya sel'skohozyajstvennyh kul'tur (Moskva, Kolos, 1985)

10. N.S. Orlova, I.YU. Kanevskaya, O.M. Kasynkina (Saratov, FGBOU VPO «Saratovskij GAU», 2011)

11. E. P. Meleshkina, Hleboprodukty, 7 (2015)

12. T.N. Tertychnaya (dis. d-ra s-h. nauk, Moskva, 2010)

13. M. Bartnik, J. Kunikowska, Forest and Wood Technol, 19 (1991)

14. M. Ben Salem, R. Bouraoui, International Journal of Dairy Science, 3, 4 (2008)

15. G. H. J. Kema, J. G. Annone, R. Sayoud, C. H. Van Silfhout, M. Van Ginkel, J. De Bree, Phytopathology, 86, 2 (1996)

16. M. Komatsuzaki, M. G. Wagger, Journal of Soil and Water Conservation, 70, 6 (2015)

17. M. Lema, E. Cebert, V. Sapra, Journal of Sustainable Agriculture, 23, 4 (2004)

18. M. Lema, E. Cebert, V. Sapra, Journal of Sustainable Agriculture, 26, 3 (2005)

19. B. Loubet, C. Decuq, E. Personne, R. S. Massad, C. Flechard, O. Fanucci, P. Cellier, Biogeosciences, 9, 4 (2012)

20. M. B. Salem, R. Bouraoui, Livestock Research for Rural Development, 20, 10 (2008) 
21. B. Serby, Society, 55, 4 (2018)

22. R. A. Shah, S. Javid, A. Inam, Environment and Conservation, 10, 2 (2004)

23. A. M. Zhukov, M. V. Anosova, I. A. Popov, S. Y. Churikova, D. S. Schedrin, Paper presented at the IOP Conference Series: Earth and Environmental Science, 422,1 (2020) 